\title{
ATRIBUT PRIORITAS UNTUK PERBAIKAN MUTU PRODUK KOKTAIL CARICA CV XYZ BERDASARKAN TINGKAT KEPUASAN DAN KEPENTINGAN KONSUMEN
}

\section{Priority Attributes for Quality Improvement of CV XYZ Carica Cocktail Product Based on Customer Importance and Satisfaction Level}

\author{
Ervina Mela*, V. Prihananto dan Arista Savira Raharjaningtyas \\ Program Studi Teknologi Pangan, Universitas Jenderal Soedirman, Purwokerto \\ Kampus Jurusan Teknologi Pertanian Jl. Dr. Soeparno Karang Wangkal, Purwokerto 53123
}

Alamat korespondensi: ervina.mela@unsoed.ac.id

\begin{abstract}
ABSTRAK
CV XYZ merupakan salah satu UMKM di Kabupaten Wonosobo yang mengolah buah carica menjadi koktail. Semakin ketatnya persaingan produk sejenis, perusahaan berusaha untuk terus meningkatkan mutu produknya dengan cara memperbaiki atribut produk yang masih lemah. Tujuan dari penelitian ini adalah untuk mengidentifikasi atribut prioritas untuk perbaikan mutu koktail carica CV XYZ berdasarkan kepuasan dan kepentingan konsumen. Atribut mutu produk dikelompokkan berdasarkan dua parameter yaitu buah carica, dan sirup koktail. Penelitian dilakukan dengan menyebarkan kuesioner kepada 100 responden secara purposive sampling. Data dianalisis menggunakan Importance Performance Analysis. Atribut prioritas untuk perbaikan mutu produk adalah banyaknya sirup dan aftertaste. Hasil penelitian menunjukan bahwa perbaikan dalam peningkatan mutu koktail carica berupa penambahan sirup dan pengujian sensoris aftertaste sirup dengan melibatkan panelis ahli.
\end{abstract}

Kata kunci: koktail carica, tingkat kepuasan, tingkat kepentingan

\section{ABSTRACT}

CV XYZ is one of the MSMEs that processes carica fruit into carica cocktails in Wonosobo Regency. The increasing intense competition for similar products, the company is determined to improve the quality of its products by improving weak product attributes. The objective of this study was to identify the priority attributes of CV XYZ carica cocktail quality improvement based on the level of satisfaction and consumer interest. The product quality attributes are grouped based on two parameters i.e. carica fruit and cocktail syrup. The study was conducted by distributing questionaires to 100 respondents by purposive sampling. The data were analyzed using Importance Performance Analysis. The priority attributes to improve the product quality were the amount of syrup and aftertaste. The result showed that improvement the quality of carica cocktails could be done by the addition of syrup and sensory testing of syrup aftertaste by involving expert panelists.

Keywords: carica coktail, consumer satisfaction, importance level

\section{PENDAHULUAN}

Buah carica merupakan buah pepaya khas yang hanya tumbuh di daerah dataran tinggi Dieng Wonosobo. Keberadaan buah carica di daerah ini sangat melimpah dan potensial untuk diolah. Menurut Dewi dan Santosa (2017), di Kabupaten Wonosobo pada 2015 , terdapat sebanyak 64.710 pohon carica, dan dihasilkan buah sebanyak 9.972 kuintal. Hal ini meningkat dari jumlah produksi di tahun 2014 yang hanya menghasilkan buah sebanyak 33.849 kuintal dari 62.642 pohon.

Buah carica tidak begitu disukai bila dikonsumsi dalam bentuk segarnya. Hal ini disebabkan karena adanya rasa gatal di mulut ketika dikonsumsi (Wulan et al., 2019). Oleh karena itu, buah ini kemudian 
p-ISSN: 1410-0029; e-ISSN2549-6786

Agrin Vol. 24, No. 2, Oktober 2020

diolah oleh masyarakat pada skala UMKM menjadi koktail carica. Koktail carica yang dimaksud ini adalah manisan buah carica yang diberi sirup lalu dikemas dalam wadah kecil yang berupa cup plastik.

Perkembangan UMKM koktail carica sangat pesat di Kabupaten Wonosobo. Menurut Dinas Perdagangan, Koperasi dan UMKM Kabupaten Wonosobo (2015), pelaku usaha UMKM carica pada tahun 2001 masih berjumlah 8 UMKM dan pada tahun 2015 meningkat menjadi 147 UMKM. Salah satu UMKM pengolahan koktail carica di Wonosobo adalah CV XYZ. Produk dari perusahaan ini telah mendapatkan penghargaan pada tingkat nasional sebagai produk favorit yang mendapat kepuasan konsumen tertinggi pada tahun 2017. Namun demikian, semakin pesatnya pertumbuhan usaha koktail carica di Wonosobo berdampak terhadap semakin ketatnya persaingan usaha dan tingginya tuntutan konsumen di pasar bebas (Cleveland dan Bartsch, 2019). Hal ini memacu UMKM untuk dapat berinovasi dalam mempertahankan bahkan terus meningkatkan mutu produk.

Menurut Tjiptono (2008), kata kunci utama dalam menghadapi persaingan adalah memberikan nilai dan kepuasan kepada pelanggan melalui penyampaian produk dan jasa bermutu dengan harga bersaing. Magutu et al. (2010) juga menyatakan bahwa mutu produk merupakan faktor kunci dalam meningkatkan daya saing perusahaan di era global.

Mutu produk merupakan kumpulan parameter dan atribut yang menjadi indikator atau menunjukkan sifat-sifat yang harus dimiliki suatu bahan atau produk pangan. Mutu utama dari koktail carica dapat dinilai berdasarkan parameter buah carica dan sirup. Penilaian konsumen khususnya mengenai kepentingan dan kepuasan terhadap kedua parameter ini penting untuk diketahui oleh produsen karena dapat memberikan penilaian mengenai produk secara objektif (Swastika et al., 2013).

Tujuan penelitian ini adalah mendapatkan atribut prioritas untuk peningkatan mutu berdasarkan tingkat kepentingan dan kepuasan konsumen. Hasil penelitian diharapkan dapat membantu perusahaan untuk memfokuskan upaya peningkatan mutu produk koktail carica supaya produk semakin dapat diterima oleh konsumen secara luas.

\section{METODE PENELITIAN}

Penelitian dilaksanakan di pusat penjualan koktail carica CV XYZ yang terletak di Kabupaten Wonosobo, Provinsi Jawa Tengah, dari Oktober sampai dengan Desember 2017. 
Tahapan penelitian terdiri atas penyusunan kuesioner, penyebaran kuesioner dan analisis data.

a. Penyusunan kuesioner

Kuesioner disusun untuk mengetahui tingkat kepuasan (kenyataan yang dirasakan) dan kepentingan (harapan) konsumen terhadap 2 parameter mutu produk koktail carica CV XYZ. Parameter dikembangkan dari penelitian Lisarini (2017) yang mencakup buah dan sirup. Parameter buah tersusun oleh 7 atribut yang meliputi cita rasa buah (B1), warna buah (B2), banyaknya buah (B3), aroma buah (B4), keasaman buah (B5), ukuran potongan buah (B6), dan tekstur buah (B7). Adapun parameter sirup tersusun oleh 6 atribut yaitu cita rasa sirup (S1), warna sirup (S2), kejernihan sirup (S3), banyaknya sirup (S4), rasa manis sirup (S5), aftertaste sirup (S6).

Penilaian tingkat kepuasan dan kepentingan konsumen terhadap seluruh atribut dilakukan dengan kuesioner berskala ordinal berikut ini (Marimin, 2004).

$5=$ Sangat Puas/sangat penting

$4=$ Puas/penting

$3=$ Netral

$2=$ Tidak Puas/tidak penting

$1=$ Sangat Tidak Puas/sangat tidak penting

Kuisioner diuji validitas dan realibilitasnya untuk melihat kualitas kuisioner yang digunakan (Yusuf, 2016).
Uji validitas digunakan untuk menunjukkan sejauh mana suatu alat pengukur mampu mengukur apa yang ingin diukur. Sedangkan uji reliabilitas digunakan untuk mengetahui sejauh mana suatu hasil pengukuran relatif konsisten apabila pengukuran diulang dua kali atau lebih. Pertanyaan pada kuesioner mempunyai $r$ hitung lebih besar dari 0.196, ini berarti bahwa kuesioner yang digunakan valid. Adapun nilai kritis dari realibilitas kuesioner adalah sebesar 0,86 (di atas nilai indeks reliabilitas instrumen sebesar 0.7), maka kuesioner dinyatakan reliabel (Widoyoko, 2016).

b. Penyebaran kuesioner

Jumlah konsumen yang menjadi responden sebanyak 100 orang ditentukan melalui rumus Lemeshow dengan metode pengambilan sampling purposive insidental sampling. Responden adalah konsumen yang sedang berbelanja di pusat penjualan CV XYZ dengan kriteria telah membeli sekaligus mengonsumsi produk koktail carica CV XYZ selama minimal 2 kali dalam 6 bulan terakhir. Profil responden yang mengisi kuesioner dapat dilihat pada Gambar 1.

c. Analisis Data

Data dianalisis berdasarkan tingkat kepentingan dan kepuasan, dengan metode Importance Performance Analysis (IPA) (Rangkuti, 2018). 


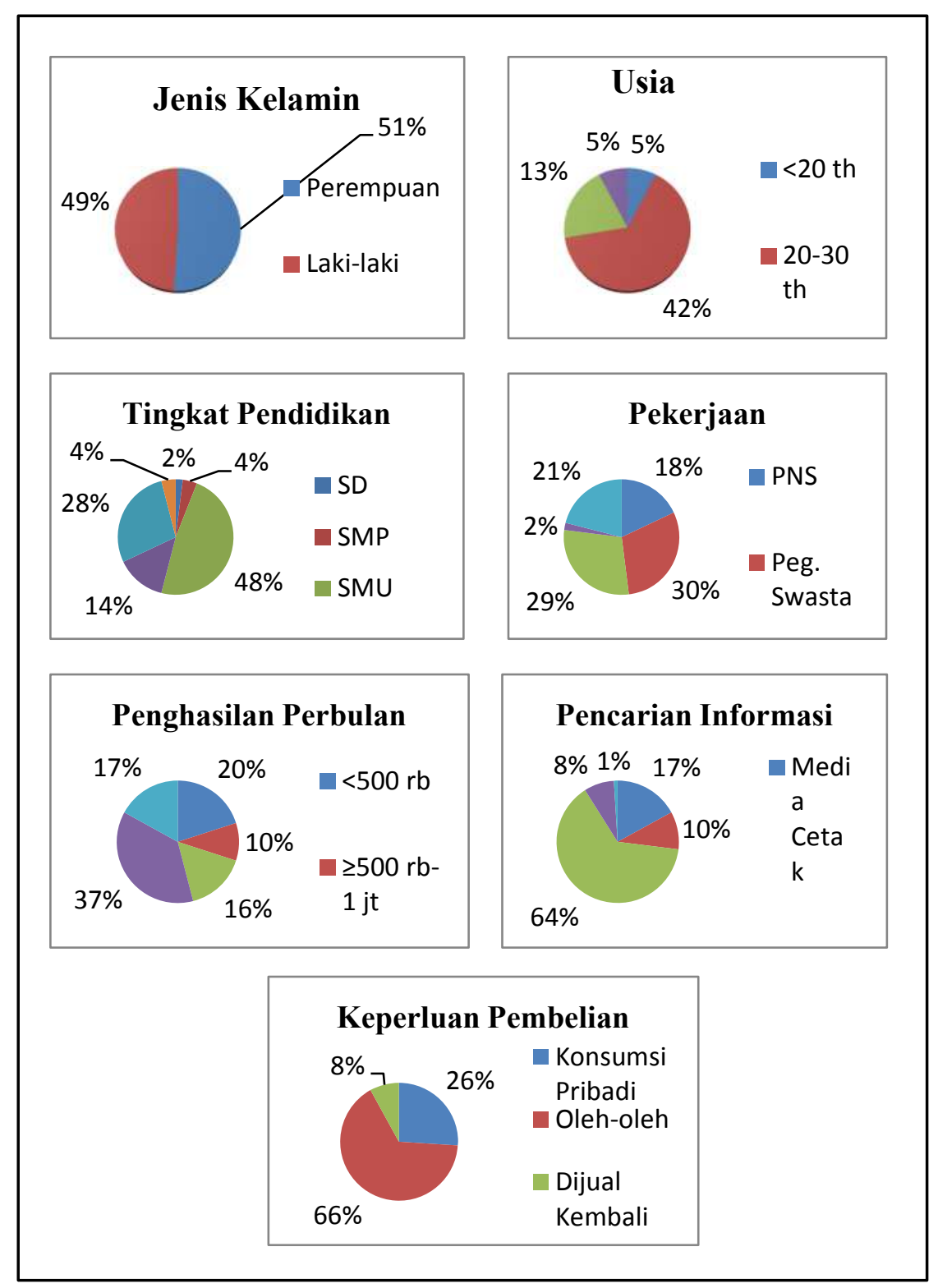

Gambar 1. Profil responden penelitian

1. Penentuan tingkat kepentingan dan kepuasan

Tingkat kepentingan dan tingkat kepuasan untuk setiap atribut dihitung dengan rumus sebagai berikut.

$$
\bar{X}=\frac{\sum X_{i}}{n} \quad \bar{Y}=\frac{\sum Y_{i}}{n}
$$

Keterangan:

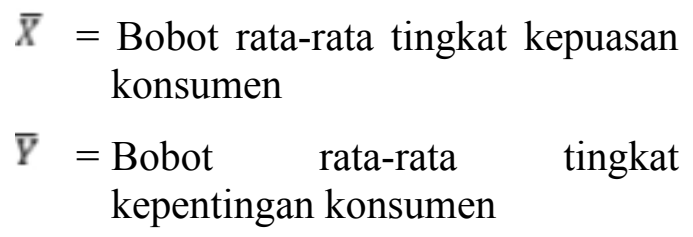

$\mathrm{n}=$ Jumlah responden/sampel

2. Penggolongan Atribut ke dalam Kuadran

Pada analisis IPA, empat kuadran yang dibatasi oleh dua garis yang berpotongan tegak lurus pada titik-titik (Q,P), dipetakan dalam diagram kartesius (Darini et al., 2017). Titik-titik tersebut diperoleh dari rumus:

$$
\mathrm{Q}=\frac{\sum \overline{X \imath}}{k} P=\frac{\sum \overline{Y l}}{k}
$$

Keterangan : 
$\mathrm{Q}=$ batas sumbu $\mathrm{X}$ (tingkat kepuasan)

$\mathrm{P}=$ batas sumbu $\mathrm{Y}$ (tingkat kepentingan)

$\mathrm{k}$ = banyaknya atribut yang mempengaruhi kepuasan responden

Menurut Rangkuti (2018) penjelasan dari tiap kuadrannya adalah sebagai berikut

a. Kuadran A (kiri atas): Prioritas Perbaikan

Menunjukkan atribut-atribut yang dirasa sangat penting bagi konsumen, namun pihak perusahaan belum melaksanakannya sesuai dengan harapan konsumen sehingga menjadi atribut prioritas perbaikan mutu produk.

b. Kuadran B (kanan atas): Pertahankan Prestasi

Menunjukkan atribut-atribut atmosfer yang dirasa penting bagi konsumen, dan pihak perusahaan telah melaksanakannya sesuai dengan harapan konsumen sehingga perusahaan perlu mempertahankan.

c. Kuadran C (kiri bawah): Prioritas Rendah

Menunjukkan atribut-atribut yang dirasa kurang penting bagi pelanggan dan pelaksanaan perusahaan masih kurang baik sehingga perusahaan dapat meningkatkan kinerjanya namun tidak menjadi prioritas. d. Kuadran D (kanan bawah): Berlebihan

Menunjukkan atribut-atribut yang dirasa tidak penting bagi konsumen, namun pelaksanaannya oleh perusahaan sangat baik sehingga apabila diperlukan upaya efisiensi biaya, maka perusahaan dapat menyesuaikan atribut ini, sesuai dengan kepentingan konsumen.

\section{HASIL DAN PEMBAHASAN}

Tingkat Kepentingan dan Kepuasan Konsumen terhadap Buah Carica

Buah carica yang diperoleh perusahaan berasal dari pemasok, yaitu para pedagang dan petani tanaman carica. Perusahaan menetapkan beberapa standar mutu buah yang dapat diterima, yaitu buah carica harus matang pohon/tua (tidak diperam), kulit berwarna hijau kekuningan sampai kuning, tidak terlalu muda, tidak terlalu tua, tidak pecah, tekstur keras-agak lunak/kenyal, aroma harum khas buah carica dan ukuran buah berdiameter minimum $4 \mathrm{~cm}$. Penetapan standar mutu buah carica yang ketat ini, dilakukan untuk menjamin kualitas produk yang dihasilkan.

Hasil penelitian mengenai tingkat kepuasan dan kepentingan konsumen terhadap parameter buah pada koktail carica dapat dilihat pada Tabel 1. Setelah dilakukan pemetaan dengan menggunakan diagram kartesius didapat hasil bahwa 
Tabel 1. Tingkat kepuasan dan kepentingan konsumen terhadap parameter buah carica

\begin{tabular}{lcc}
\hline \multicolumn{1}{c}{ Atribut } & Kepuasan (X) & Kepentingan (Y) \\
\hline Cita rasa buah (B1) & 4,49 & 4,05 \\
Warna buah (B2) & 4,21 & 3,91 \\
Banyaknya buah (B3) & 3,84 & 3,87 \\
Aroma buah (B4) & 4,28 & 4,50 \\
Keasaman buah (B5) & 3,85 & 4,00 \\
Ukuran potongan buah (B6) & 3,94 & 3,70 \\
Tekstur buah (B7) & 4,25 & 4,18 \\
\hline Jumlah & 28,86 & 28,21 \\
\hline Batas Sumbu & $\mathrm{X}: 28,86 / 7=4,123$ & $\mathrm{Y}: 28,21 / 7=4,03$ \\
\hline
\end{tabular}

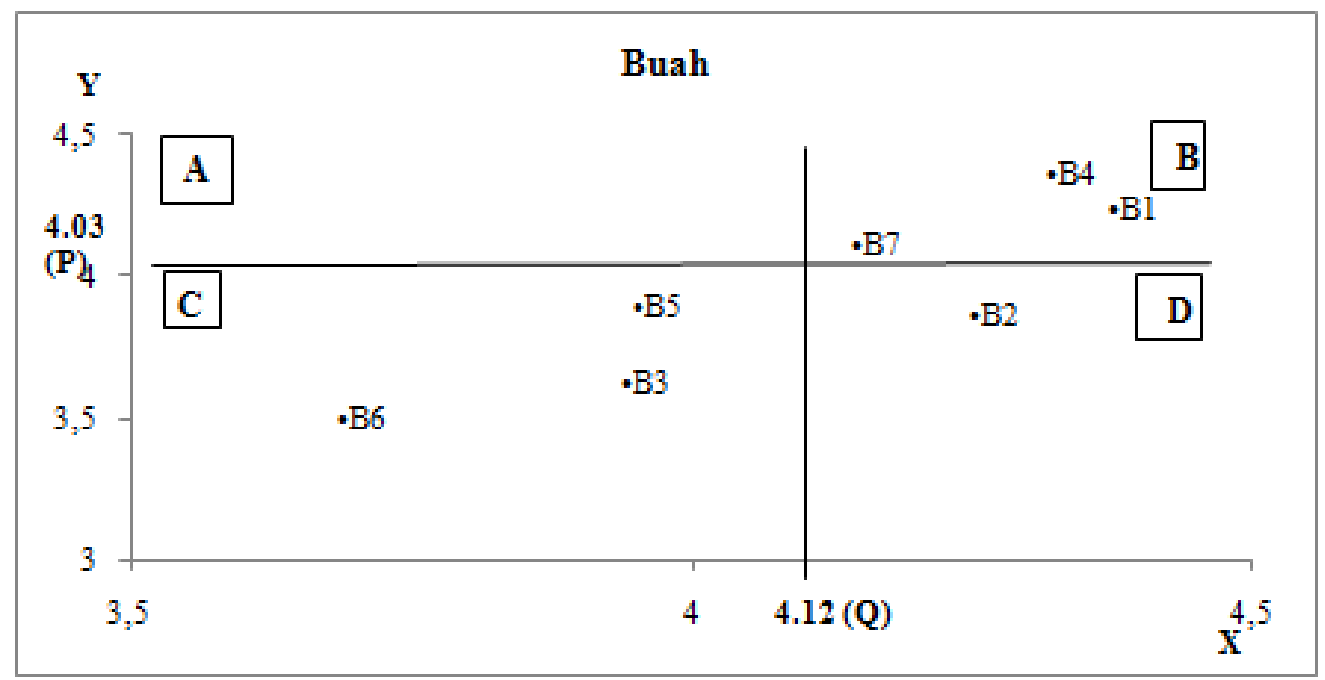

Gambar 2. Diagram Kartesius Importance Performance Analysis parameter buah carica.

atribut-atribut dalam parameter buah hanya tersebar ke dalam 3 kuadran, yaitu kuadran B, C dan D (Gambar 2). Atribut yang berada pada kuadran B merupakan atribut yang harus dipertahankan yaitu cita rasa buah, aroma buah, dan tekstur buah. Atributatribut yang berada pada kuadran $\mathrm{C}$ merupakan atribut proritas rendah yaitu banyaknya buah, keasaman buah, dan ukuran potongan buah. Atribut yang berada pada kuadran D merupakan atribut yang berlebihan yaitu warna buah, sedangkan pada kuadran A tidak terdapat atribut artinya untuk parameter buah tidak terdapat atribut yang harus diperbaiki.

Walaupun secara umum parameter buah telah dinilai baik dan memuaskan oleh konsumen namun perusahaan harus terus mempertahankan kualitas sehubungan dengan parameter buah ini demi mempertahankan kepuasan konsumen. Rahayu dan Pribadi (2012) berdasarkan hasil penelitiannya, telah memberikan rekomendasi bahwa untuk dapat diterima oleh konsumen maka produsen koktail carica harus sangat memperhatikan tekstur, rasa, warna dan aroma produk serta dapat 
mempertahankan kadar gizi yang tinggi. Hal ini didukung Rahayu et al. (2018), yang dari penelitiannya terhadap koktail nanas, menyatakan bahwa bahwa rasa, aroma, warna buah mempengaruhi penerimaan panelis.

\section{Tingkat Kepentingan dan Kepuasan Konsumen terhadap Sirup Koktail Carica}

Hasil penelitian mengenai tingkat kepuasan dan kepentingan konsumen terhadap parameter sirup pada koktail carica dapat dilihat pada Tabel 2. Setelah dilakukan pemetaan dengan menggunakan diagram kartesius (Gambar 3) diketahui bahwa atribut-atribut pada parameter sirup tersebar di 4 kuadran yang berbeda. Atribut yang berada di kuadran A yaitu banyaknya sirup dan aftertaste sirup, pada kuadran B yaitu cita rasa sirup, kuadran $\mathrm{C}$ yaitu atribut tingkat kekoktail sirup, atribut yang berada di kuadran D yaitu warna sirup dan kejernihan sirup. Atribut pada kuadran A yaitu banyaknya sirup dan aftertaste, merupakan atribut yang harus diperbaiki. Sedangkan atribut pada kuadran B yaitu cita rasa sirup merupakan atribut yang harus dipertahankan.

Tabel 2. Tingkat kepuasan dan kepentingan konsumen terhadap parameter sirup koktail carica

\begin{tabular}{lcc}
\hline \multicolumn{1}{c}{ Atribut } & Kepuasan (X) & Kepentingan (Y) \\
\hline Cita rasa sirup (S1) & 4,32 & 4,53 \\
Warna sirup (S2) & 4,20 & 4,24 \\
Kejernihan sirup (S3) & 4,25 & 4,28 \\
Banyaknya sirup (S4) & 3,96 & 4,32 \\
Kemanisan sirup (S5) & 4,11 & 4,17 \\
Aftertaste sirup (S6) & 4,13 & 4,36 \\
\hline Jumlah & 24,97 & 25,90 \\
\hline Batas Sumbu & $\mathrm{X}: 24,97 / 6=4,17$ & $\mathrm{Y}: 25,9 / 6=4,32$ \\
\hline
\end{tabular}

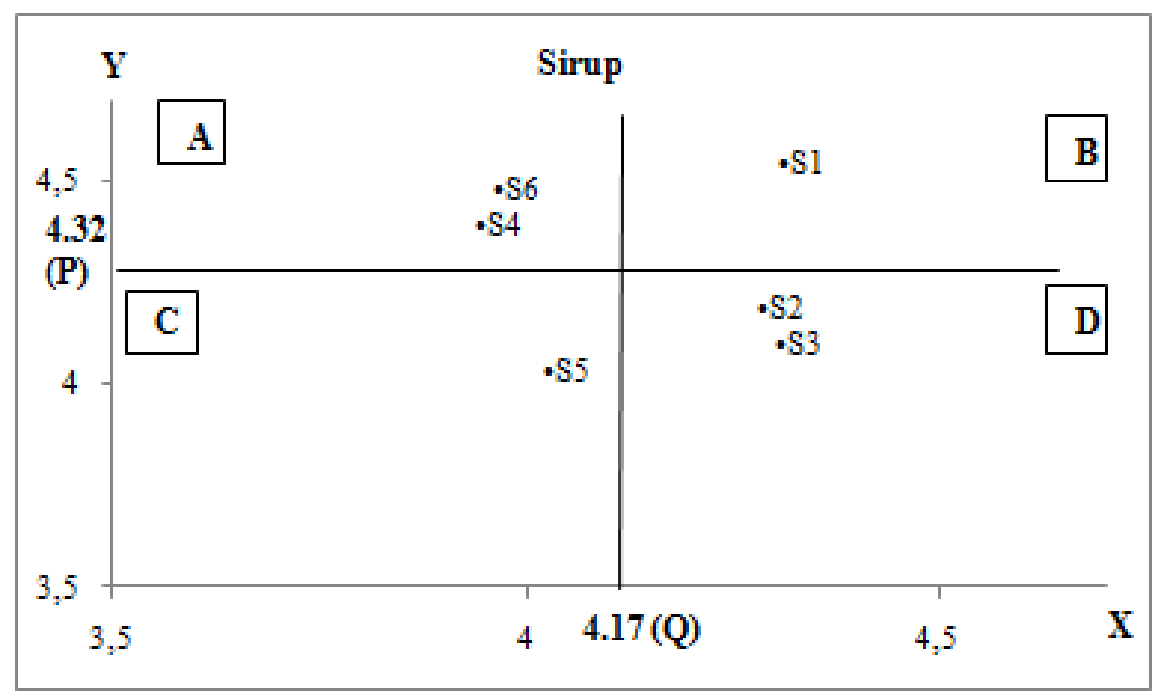

Gambar 3. Diagram Kartesius Importance Performance Analysis Parameter Sirup 
Atribut Prioritas Berdasarkan Parameter Sirup yang Perlu Diperbaiki

\section{Banyaknya Sirup}

Sebagian besar konsumen merasa belum puas terhadap atribut banyaknya sirup pada koktail carica (nilai kepuasan masih di bawah angka 4) dan berpendapat bahwa sirup yang terdapat pada koktail carica jumlahnya masih kurang banyak. Hasil penelitian Yustitia (2012), menyatakan bahwa volume sirup memang merupakan salah atribut yang dinilai penting oleh konsumen pada produk minuman. Penelitian Rahmasari et al. (2017), pada produk minuman Teh Kotak menunjukan bahwa volume minuman berpengaruh terhadap kepuasan, ternyata juga memberikan pengaruh yang positif terhadap sikap dan konsistensi konsumen dalam mengonsumsi produk. Konsumen pada minuman Teh Kotak lebih memilih produk ini dibandingkan produk lain karena adanya tambahan ekstra isi 50\% dibandingkan produk sejenis. Tambahan ekstra isi $50 \%$ telah menjadi atribut yang sangat melekat pada pilihan konsumen sebagai salah satu ciri khas dari minuman ini, dan menjadi pertimbangan kuat dalam memilih produk dibanding produk lain.

Pada pemasaran, strategi yang dilakukan oleh Teh Kotak ini dikenal sebagai strategi positioning (Kotler dan Keller, 2009). Menurut Hidayat (2017) strategi positioning ini sangat diperlukan pada kondisi persaingan yang ketat. Hal ini dibuktikan dari penelitian minuman $\mathrm{Nu}$ Green Tea, yang menerapkan strategi positioning, mampu menjadi pemimpin pasar minuman teh dalam kemasan dengan penguasaan pasar $50 \%$.

Ditinjau dari aspek teknologi pangan, penambahan sirup juga dapat berpengaruh positif kepada umur simpan produk. Sirup pada koktail selain sebagai pengawet juga dapat menambah cita rasa dan tingkat kesukaan konsumen (Rahayu et al., 2018). Gula pada sirup secara perlahan akan meresap ke dalam buah, dengan demikian kadar gula dalam jaringan cukup tinggi sehingga dapat mencegah pertumbuhan mikroorganisme pembusuk (Retnawaty dan Wirman, 2015). Umur simpan yang lebih panjang diharapkan dapat meningkatkan kepuasan konsumen, karena konsumen dapat menyimpan dan mengonsumsi produk lebih lama.

Oleh karena itu sangat disarankan bagi CV XYZ untuk menambah volume sirup dalan rangka meningkatkan kepuasan konsumen terhadap koktail buah carica. Penambahan volume sirup ini berpotensi mendorong sikap positif terhadap produk, dan mempertahankan konsistensi konsumen dalam memilih produk. Sehubungan dengan hal ini, perusahaan juga harus melakukan penelitian, mengenai banyaknya sirup yang dapat ditambahkan 
dengan mempertimbangkan ukuran dan kekuatan kemasan koktail buah carica.

\section{Aftertaste Sirup}

Aftertaste merupakan sensasi yang dirasakan oleh penginderaan atau sensoris setelah makanan atau minuman dikonsumsi (Stone et al., 2012). Beberapa konsumen masih merasakan adanya aftertaste pahit setelah mengonsumsi sirup dari koktail carica. Menurut Adawiyah et al. (2020) hal ini dapat disebabkan oleh penambahan bahan tambahan makanan. Penggunaan pemanis artifisial ataupun alami dalam produk pangan seringkali mengubah persepsi rasa produk, tidak hanya rasa manis yang dirasakan pada produk tetapi karakteristik lain seperti rasa pahit, ataupun metallic aftertaste (purna rasa metalik).

Pada produksi koktail carica CV XYZ selain menambahkan gula, juga menambahkan asam sitrat yang berfungsi sebagai penguat rasa asam, Natrium benzoat sebagai pengawet, dan food colour Sunset Yellow FCF sebagai pewarna. Penggunaan bahan pengawet dan asam sitrat sudah memenuhi kriteria yang ditetapkan pemerintah terkait penggunaan bahan tambahan pangan (BTP). Saran yang dapat diberikan kepada perusahaan sehubungan dengan masalah aftertaste adalah melakukan pengecekan kembali dengan melibatkan panelis ahli yang yang benar-benar terlatih untuk melakukan evaluasi sensoris khususnya terhadap aftertaste sirup koktail carica. Apabila ditemukan hasil seperti yang dikatakan oleh kebanyakan konsumen pada penelitian ini maka ada baiknya perusahaan memformulasikan kembali penggunaan BTP yang digunakan.

Tarwendah (2017) menyatakan bahwa evaluasi sensori dapat dibagi ke dalam dua kategori yaitu pengujian objektif dan subjektif. Dalam pengujian objektif atribut sensori produk dievaluasi oleh panelis terlatih. Sedangkan pada pengujian subjektif atribut sensori produk diukur oleh panelis konsumen. Pengujian secara panel ini penting dalam pengembangan produk dengan meminimalkan resiko dalam pengambilan keputusan. Panelis dapat mengidentifikasi sifat-sifat sensori yang akan membantu untuk mendeskripsikan produk. Perusahaan perlu melakukan evaluasi sensoris ini secara berkala, karena menurut Lawless dan Heymann (2013), evaluasi sensoris bermanfaat pada kegiatan pengembangan produk baru, mulai dari formulasi, modifikasi bahan baku dan ingrediens, pengurangan biaya, quality maintanance, dan hingga optimalisasi produk.

\section{KESIMPULAN}

Berdasarkan tingkat kepentingan dan kepuasan konsumen, atribut prioritas untuk perbaikan mutu koktail buah carica 
produksi CV XYZ adalah volume sirup dan aftertaste.

\section{DAFTAR PUSTAKA}

adawiyah, D. R., Puspitasari, D. dan Lince, L. 2020. Profil sensori deskriptif produk pemanis tunggal dan campuran. Jurnal Teknologi Dan Industri Pangan, 31: 9-20.

Cleveland, M. dan Bartsch, F. 2019. Global consumer culture: epistemology and ontology. International Marketing Review, 36(4):556-580.

Darini, M. A. W., Hartiati, A. dan Wiranatha, A. S. 2017. Analisis kepuasan konsumen terhadap kualitas produk dan pelayanan dengan menggunakan metode importance performance analysis (studi kasus di angkringan jinggo $\mathrm{Bu}$ Jero, Kediri Tabanan). Jurnal Rekayasa Dan Manajemen Agroindustri, 5: 61-70.

Dewi, R. K. dan Santosa, P. B. 2017. Analisis rantai nilai komoditas buah carica di kecamatan kejajar kabupaten wonosobo. Disertasi. Fakultas Ekonomika Dan Bisnis Universitas Diponegoro, Semarang.

Dinas Perdagangan, K. D. U. K. W. 2015. Jumlah produksi papaya 2013-2015. Pemerintah Kabupaten Wonosobo.

Hidayat, R. S. 2017. Analisis pengaruh strategi segmenting, targeting dan positioning terhadap keputusan pelanggan membeli $\mathrm{Nu}$ Green Tea. Jurnal Ekonomika dan Manajemen, 6: 28-43.

Kotler, P. dan Keller. 2009. Manajemen pemasaran jilid i (ed 13). Erlangga, Jakarta.

Lawless, H. T. dan Heymann, H. 2013. Sensory evaluation of food: principles and practices. Springer Science \& Business Media, New York.
Lisarini, E. 2017. Atribut manisan buah basah Cianjur yang mempengaruhi preferensi konsumen. Agroscience, 7: 226-233.

Magutu, P. O., Nyamwange, S. O. dan Kaptoge, G. K. 2010. Business process re-engineering for competitive advantage. African Journal Of Business And Management, 1:135-150.

Marimin. 2004. Pengambilan keputusan kritera majemuk: teknik dan aplikasi. Grasindo, Bogor.

Rahayu, E. S. dan Pribadi, P. 2012. Kadar vitamin dan mineral dalam buah segar dan manisan basah karika dieng (Carica pubescens lenne\&k. koch). Biosaintifika, 4: 89-97.

Rahayu, W. E., Mukminah, N. dan Romalasari, A. 2018. Daya terima varian rasa koktail buah nanas (ananas comosus 1. merr) dalam menunjang diversifikasi produk. jurnal Ilmiah Ilmu Dan Teknologi Rekayasa, 1: 24-29.

Rahmasari, L. F., Nurmalina, R. dan Priatna, W. B. 2017. Analisis sikap, konsistensi dan kepuasan pada teh kotak Ultrajaya. Forum Agribisnis, 85-102.

Rangkuti, F. 2018. Measuring customer satisfaction teknik mengukur strategi meningkatkan kepuasan pelanggan. Gramedia Pustaka Utama, Jakarta.

Retnawaty, S. F. dan Wirman, S. P. 2015. Uji fisis dan ph manisan air buah kolang-kaling. Photon: Jurnal Sain Dan Kesehatan, 5: 53-62.

Stone, H., Bleibaum, R. N. dan Thomas, H. A. 2012. Sensory evaluation practices. Academic Press. Elsevier. Amsterdam.

Swastika, N., Yanto, T. dan Hartati, A. 2013. Performansi kualitas atribut beras organik dan tingkat kepuasan 
konsumen beras organik di kabupaten sragen. Agrin, 17: 103-112.

Tarwendah, I. P. 2017. Jurnal review: studi komparasi atribut sensoris dan kesadaran merek produk pangan. Jurnal Pangan Dan Agroindustri, 5: 66-73.

Widoyoko, E. P. 2016. Teknik Teknik Penyusunan Instrumen Penelitian. Pustaka Pelajar, Yogyakarta.

Wulan, S. S., Su'i, M. dan Sumaryati, E. 2019. Pengaruh konsentrasi garam dan lama perendaman terhadap mutu manisan carica (Carica pubescens). Agrika, 13: 23-32.

Yustitia, A. 2012. Atribut kepuasan konsumen produk minuman ringan coca cola di Kota Bandarlampung. Jurnal Teknologi \& Industri Hasil Pertanian, 14: 45-54.

Yusuf, A. M. 2016. Metode Penelitian kuantitatif, kualitatif dan penelitian gabungan. Prenada Media, Jakarta. 